\title{
Trade-Union Internationalism and Solidarity in the Struggle against Apartheid: A Case Study of Volkswagen
}

\section{Chris Bolsmann}

By the 1970s, the struggle against apartheid had intensified within South Africa and abroad. Eddie Webster has argued that this struggle 'became the moral equivalent of the Spanish civil war ... with democrats, liberals, communists and concerned Christians united in common abhorrence of white domination'. 1 This article focuses on the trade-union internationalism and solidarity that emerged between South African and German trade-unionists in the fight against apartheid in a major German trans-national corporation (TNC). The relationships that developed in terms of the overlapping and convergence of economic, political and institutional interests that inform actions are studied.2 Two distinct phases are identified. First, the emergence in the latter part of the 1970s of direct shop-floor and official links between South African and German trade-unionists, informed by the economic and institutional interests of the trade unions and the company involved. Second, new relationships and structures developed in the early 1980s that were informed by political interests of the actors and the German churches, in particular. The tensions between narrow forms of economically determinist trade-union internationalism and more encompassing political activity and solidarity can therefore be identified.

\section{Trade unions and the struggle against apartheid}

After the electoral victory of the National Party in South Africa in 1948, trade unions were separated into racial organizations, job reservation was enforced by statute to protect and promote white employment, and the government refused to recognize black unions.3 In 1955, the South African Congress of Trade Unions (SACTU) 4 was established and from the outset 'chose to play a political role' 5 and 'adopted a higher political profile'.6 By 1957, SACTU had joined the Congress Alliance that included the African National Congress (ANC) and participated in a variety of political campaigns. After the Sharpeville massacre of 1960, the ANC was banned and embarked on the armed struggle. SACTU was not banned but, as many of its activists were members of the ANC, 'almost [the] entire SACTU leadership were recruited' into Umkhonto we Sizwe (MK), the armed wing of the ANC.7 A number of SACTU officials were banned by the government and 'by 1965 SACTU as an internal federation of unions was effectively dead'.8 SACTU went into exile and a variety of reasons have been identified as to why it was destroyed within the country. Steven Friedman argued that SACTU had become 'captives of the nationalists' with the organization's 'submission to the nationalist movement now reached its logical conclusion: scores of its officials abandoned union work to take up arms'.9 Jeremy Baskin draws on Rob Lambert10 and argues that SACTU's political engagement did not destroy the organization but rather strengthened it. The mass arrests and the armed struggle are identified as further reasons why SACTU was hampered.11 The result was that by 1965 black trade-union organization and resistance was severely restricted. But as the South African economy then grew at unprecedented levels, this led to renewed worker resistance and organization. 
The 1973 Durban strikes marked the return of black-worker resistance and the formation of independent trade unions; 12 within the first three months over 60,000 African workers had struck.13 This militancy 'heralded the start of the resurgence of African trade unionism in the country as whole'.14 As a consequence of the strikes, the Guardian newspaper in Britain published articles on wages paid to African workers in British multi-nationals in Durban. This resulted in a House of Commons Select Committee investigation into practices of British firms in apartheid South Africa. 15

While the re-emerging trade unions began to organize within South Africa, apartheid increasingly became an international issue. The role played by the AntiApartheid Movement in Britain and Sweden has been considered in recent publications, 16 but the role played by trade unions is seen as secondary. Relatively few studies have specifically focused on trade-union internationalism and the struggle against apartheid.17 Roger Southall's study represents the most significant contribution, as it provides a sweeping and detailed overview of tradeunion internationalism and solidarity with labour in South Africa.18

According to Southall, three conclusions can be drawn from the South African experience of international labour solidarity.19 First, the extent and reach of solidarity was impressive rather than dramatic. The combination of rank-and-file and official involvement resulted in principled actions that were 'systematically and comprehensively developed'.20 Second, because of Cold War tensions at the level of the International Confederation of Free Trade Unions (ICFTU), the International Trade Secretariats and SACTU, effective solidarity was restricted. SACTU acted as a gatekeeper and attempted to monopolize all international trade-union work. Finally, established union centres in Europe and North America had direct access to conservative Western governments which were able to apply pressure for policy changes, whereas the more radical voices such as the Anti-Apartheid Movement were unable to do so. In addition, Southall notes that "direct links" required international coordination which transcontinental shopfloor and even union-to-union contacts were not geared up to provide'.21

Southall's analysis primarily considers the role of national union centres in Britain, Canada and the United States. He does not explore the German contribution in much detail. His research also does not interrogate the possible differences between activities of unions and worker bodies within TNCs. Detlev Tenzer's analysis, which explores the relationship between Industriegewerkschaft Metall (IG Metall) and the independent trade-union movement in South Africa from 1972 to 1989, fills the gap left by Southall.22 Yet his study is broad and does not consider the particular histories of trans-national worker solidarity in specific firms, or the role of the churches and the Anti-Apartheid Movement in Germany. Moreover, the interests of German TNCs are not considered while the role played by the Protestant Church is significant, as will be shown. In this regard, Rainer Zoll refers to the 'moral' conceptions of solidarity involved in the actions of the Protestant Church.23

A study of the automobile industry reveals the strategic links between South African subsidiaries and the operations of TNCs. Volkswagen was chosen as the specific case study for investigation as it was the first German automobile manufacturer to invest in South Africa and has remained the largest German automobile concern in the country. Its industrial relations model of co-determination is important in Germany as a way of regulating relations between capital and labour. 
Finally, Volkswagen is the only automobile company in South Africa where significant long-term relationships24 developed between the black25 trade union within the subsidiary and the trade union and works councils in Germany.

\section{Setting the scene: Volkswagen, Germany and South Africa}

Volkswagen was established in 1934 as part of the National Socialist project in Germany and today is the fourth largest auto-manufacturer worldwide, the largest in Europe, with an $8.5 \%$ share of the world market, 26 and has the most foreign production sites of any German company (over thirty in seventeen countries). After the Second World War, Volkswagen was characterized by a standardized production system and a specific governance structure, in the context of the emerging German industrial relations model.27

Volkswagen's governance structure is unique and Ulrich Jürgens refers to it as a form of 'neo-corporatism'.28 Volkswagen was run as a state company after the British withdrew from Allied-occupied Germany in 1949, and by 1960 it had become a public-limited company (Aktiengesellschaft, AG), partially privatized. The German government and the state of Lower Saxony each acquired $20 \%$ of company shares, with the remaining $60 \%$ spread across the banking and insurance sectors. The Social Democratic composition of federal and state governments at certain periods, with Ministers of Finance and Economic Affairs and of Social and Labour Affairs representing the interests of the state as shareholders, meant that state policy was relatively friendly towards labour, and 'labour controlled the majority of Volkswagen's supervisory board'.29

The German model of industrial relations is characterized by high levels of cooperation between management and works councils. The Works Constitution Law of 1952 (Betriebsverfassungsgesetz) provides the basis for works councils and meant that unions were barred from 'an official role on the shop floor'.30 As a response, vertrauensleute (shop stewards) were introduced, to control the activities of works councillors; in practice the opposite occurred.31 Nonetheless, IG Metall played a 'vanguard' role within the West German trade unions in attempting to maximize gains from the capitalist system without offering a challenge to its legitimacy.32 The 1972 revised Works Constitution Law was passed with increased powers for works councils, greater influence over the work environment, and closer linkages with unions. In companies with more than one plant, central works councils were created.33 The 1976 Co-Determination Act allowed for participation at company level but Richard Hyman argued that this 'gave unions a victory in form but a defeat in substance'.34 The law meant employers dominated at the company level and favoured capital.35 The conflict surrounding co-determination represented 'a revival of class as a driving force of industrial relations'.36

The role played by the system of co-determination is crucial in the context of neo-corporatism, as it is independent of political parties and allegiances. The works councils exert different degrees of influence dependent on the issue under consideration. Works councillors are elected for a period of four years and candidates are nominated by the union or by employees entitled to vote. The works council ensures adherence to laws, ordinances, health and safety regulations, collective and factory agreements, and has the right to be consulted on economic 
issues and dismissals of employees as well as workplace design, human resource planning, operational changes and the introduction of new technology. The company must consider the viewpoints of the works council in decisions.

The relationship at Volkswagen is different from other companies in Germany, as collective agreements are negotiated directly with IG Metall, rather than through the employers' federation, Gesamtmetall. This makes the Volkswagen case unique, as it represents company-wide collective bargaining in which the dominant relationship is 'shortcircuited'. 37 In addition, a system of in-house collective agreements between IG Metall and Volkswagen regulate working conditions. IG Metall also dominates the works councils in the Volkswagen group through the election of worker

representatives. At Volkswagen, the General Works Council deals with issues that cannot be resolved at plant level. The Supervisory Board of Volkswagen monitors the management of the company, including its finances. It comprises ten employee representatives and ten representatives of capital, though the chair represents capital and has two votes. In addition, one employee representative originates from the category of 'managerial employee' (leitende Angestellte).

IG Metall organizes in the iron and steel, metal-processing and metal trade sector, textile and garments, and wood and plastics industry, with 2.8 million members. Its origins can be traced back to the Deutscher Metallarbeiter Verband, established in 1891, which passed on an 'ideological radicalism to IG Metall' due to experiences with conservative employers; this resulted in a trade-union policy to the left of other unions.38 IG Metall attempted to portray itself as an oppositional force but also a responsible role-player in West German society that displayed antiCommunist and anti-East-German sentiments during the Cold War. IG Metall is the largest affiliate of the International Metalworkers' Federation (IMF) and plays a dominant role in it. This is often manifested in the IMF president also being the president of IG Metall.

In South Africa, the municipality of Uitenhage, lying on the outskirts of Port Elizabeth in the eastern Cape, sold fifty acres of land to the South African Motor Assemblers and Distributors Limited (SAMAD) in 1946.39 In early 1951, SAMAD agreed to assemble the Volkswagen 'Beetle'. By 1956 the Volkswagenwerk in Wolfsburg, West Germany, acquired the controlling interest in SAMAD and an expansion programme raised production capacity from 47 to 75 units a day. Additional growth occurred in 1962 with the hourly-paid white work-force increasing from 462 to 524 and the hourly-paid black workforce from 335 to 358.40 In 1964, the Evening Post reported on Volkswagen's R8 million expansion programme and that SAMAD 'has had a notable managerial record, not least in labour relations (White and non-White)'.41 In 1966 the company's name was changed to Volkswagen of South Africa (VWSA); the government enacted legislation permitting trade-union activity for white unions and so the company began negotiations with the South African Iron, Steel and Allied Industries Union.42 By 1967, the IMF pressurized the Trade Union Council of South Africa (TUCSA) to form a separate industrial union for coloured and Indian workers and made a small grant available for this purpose.43 TUCSA had been established in 1954 and 'grew out of a fight against union apartheid'.44 But it sought to protect the interest of its white members and to control African worker organizations. In addition, it was 'extremely hostile to both Sactu and the ANC'.45 TUCSA's affiliates were often seen as conservative, 'sweetheart' and 'benefit unions'.46 The National Union of Motor Assembly Workers of South Africa was established and registered by March 1968 and affiliated to TUCSA.47 Workers 
in other sectors of the industry were organized and this was reflected in the name change to the National Union of Motor Assembly and Rubber Workers of South Africa (NUMARWOSA). By May 1969, 50\% of Volkswagen's coloured workers were organized, and in turn the union formally recognized.48

The Bantu49 Labour Relations Regulation Act of 1973 made provision for liaison committees at plant level. Management could nominate up to $50 \%$ of the delegates. The committee had no negotiation rights and 'management, supported by the state ... enthusiastically promoted liaison committees'.50 VWSA management established a Bantu Liaison Committee and claimed it was 'to discuss matters of mutual interest between management and Black employees and promote good relations'.51 Future shop stewards of the United Automobile, Rubber, and Allied Workers' Union of South Africa (UAW), established in 1973 for African workers as a parallel union to NUMARWOSA, dominated the committee.

In the late 1970s, contacts between unions in Volkswagen's South African subsidiary and its plants in Germany developed. This occurred against a backdrop of bitter debates within the South African labour movement on the nature and extent of linkages with overseas groups. During the 1960s, the ICFTU maintained relationships with TUCSA as it was regarded as the 'most representative organisation of workers'.52 TUCSA's decision to bar affiliation of African unions in 1969 resulted in ICFTU's change of strategy. SACTU's exile in London meant tradeunion partners were sought across Europe. In 1956, SACTU affiliated to the World Federation of Trade Unions (WFTU) even though it never paid affiliation fees.53 This affiliation was an important development as it "provided access to the ILO [International Labour Organization] and UN [United Nations] machinery, enabling it to maintain its stance as the most representative body of South African workers'.54

The 1973 Durban strikes were significant as an independent tradeunion movement emerged that confronted the South African state inside the country. The new unions engaged in an active international policy, being non-aligned and pragmatic in their outlook.55 This meant that South African unions were active participants in the engagement with foreign trade-union centres, and they established linkages and built relationships. This impacted on SACTU in as much as "critics argued the case for direct international working class contacts with, and support for, the new internal unions ... [and] this issue of "direct links" ... went on to compel a reassessment of trade union potential under apartheid'.56 Moreover, SACTU was no longer in a position to fulfil the role of gatekeeper for international trade-union work. The consequences were that SACTU was sidelined in the administration and maintenance of linkages and did not have access to resources generated as a result of the contact. With SACTU not in the forefront of the new emerging contacts, it suggested that internal unions would be jeopardized, class collaboration would take place and that the ANC and the Congress Alliance would be bypassed.57

\section{Initial shop-floor and official contact between South Africa and Germany}

As early as 1964, IG Metall made a financial contribution of DM 50,000 to South African exiles, 58 but the impetus for more extensive and systematic contact between South African and German labour emerged after the IMF's Munich Congress in 
1977, when South Africa became an important political consideration. After the Soweto uprising of 1976, a number of affiliates called for more effective action against apartheid South Africa. The use of violence for the liberation of South Africa was rejected and the IMF's South African affiliates (white trade unions) 'expressed their doubts as to the effectiveness of total economic sanctions'.59

IMF representatives had visited South Africa in 1972 and endorsed the position of the white affiliates, which called for parallel unionism (with white unions taking the lead role) for the different racial groups. By 1977 this position had changed and the visit by IMF representatives made an impact on trade-union recognition for black labour at Volkswagen. The IMF's Werner Thönnessen and the president of the UAW in South Africa, Johnny Mke, asked Ollie Rademeyer, labour relations manager at VWSA, to grant facilities to the UAW to organize and to allow union representatives to enter the plant and meet on the premises.60 Thönnessen and Mke met with Rademeyer and the managing director of VWSA, Peter Searle, and tabled a total of 1,016 stop-orders to deduct union subscriptions from workers' wages.61 Rademeyer commented: 'our people don't really want a union. They've got a Liaison Committee ... I couldn't believe it when they put them down on my desk and he said, "Look, we've signed up more than $50 \%$ of your black employees ... We then said our prayers".'62 After the stop-orders were checked by VWSA management, the UAW was recognized and stop-order facilities made available and the Liaison Committee abolished.

Mke visited the Friedrich-Ebert-Stiftung (located in Bonn and allied to the Sozialdemokratische Partei Deutschlands), IG Metall and the IMF in Germany. The visit and the recognition of the UAW received widespread coverage in the German press. In particular, it was reported that VWSA was the first German firm to recognize a black trade union in South Africa. In the late 1970s, Siegfried Ehlers (chair of the Central Works Council in Wolfsburg) expressed his solidarity in the struggle for human rights and equal treatment of Volkswagen workers around the world. The in-house newspaper of the Wolfsburg works council, BR kontakt, reported:

we expect the minimum from management in every subsidiary of Volkswagen around the world an elected representative of the employees and their trade unions are recognized as negotiating partners ... We realize [sic] we cannot solve the problems of Brazil, South Africa, the USA or Belgium in Wolfsburg ... but when it has to do with trade union rights then we want to and must take the initiative. 63

As a further response to the IMF's Munich Congress and the developments in South Africa, and at Volkswagen in particular, IG Metall and the IMF sent an official delegation to South Africa in January 1978. The party comprised: Eugen Loderer, chair of IG Metall and president of the IMF; Hans Mayr, vice-chair of IG Metall; Herman Rebhan, general secretary of the IMF; and Albert Schunk from IG Metall's International Department. This high-ranking delegation visited the German companies of Siemens, DEMAG, Mercedes Benz and Volkswagen, and the US concerns of General Motors and Ford. The delegation stated that, at Volkswagen, 'the general condition[s] of coloured and black workers were more extensive than at 
other German firms ... and ... at VW there is a willingness to make further steps in the direction of racial equality'.64

Two political questions emanated from the visit. First, what role an economic boycott could play, and, second, what was the possibility of building black trade unions and for the principle of unitary tradeunionism? The delegation recommended an economic boycott be a last resort. Instead, through various means, the unions should attempt to influence the South African regime. In the 1950s calls for cultural boycotts and in the 1960s sports boycotts had been made and were seen as a way of pressurizing apartheid South Africa. Not until the 1970s did disinvestments and sanctions, as part of the broader struggle and total boycott, take hold. Indeed, in 1986, General Motors disinvested from South Africa, while Ford was sold to a South African company owned by Anglo-American.

Additionally, the delegation rejected the notion of parallel unionism where separate unions existed for different racial groups and recommended an attempt at integration. It argued that the European Economic Community (EEC) Code of Conduct (September 1977), regulating foreign investment in the country and other similar proposals, needed to be considered as ways of creating effective action. The first employer codes had been developed in 1973 by the British government. The South African Labour Bulletin suggested that the Codes were 'a response to the Durban Strikes of 1973 and subsequent international exposure of the conditions of labour in South Africa'.65 Yet, more significantly, 'they are a response to the pressures abroad on foreign investors to withdraw from SA. They represent the lobby of those unwilling to support the call for withdrawal of investment'.66 In addition to the EEC Code, the Sullivan Principles, developed by Leon Sullivan, a member of General Motors Board of Directors, were formulated in February 1977. In November 1977, the South African Employers Consultative Committee on Labour and the Urban Foundation, established in 1976 by South African capital to lobby for, among other things, changes in the control of black migration into urban areas, initiated their own codes of conduct. The codes meant employer responsibilities were made public and worker rights were made visible; but the codes had serious limitations as they did not explicitly call for the recognition of trade unions representing black workers.67 Moreover, the codes were seen as 'pressure on management from outside the workplace and cannot be seen as instrumental in building an independent labour movement'.68

Hans-Jürgen Uhl, an IG Metall official and Wolfsburg works council member, explained the changing policies with regards to contacts with South Africa. He suggested that South Africa, Brazil and Mexico had become areas of concern for Volkswagen AG due to its changing international outlook.69 Volkswagen phased out German production of the Beetle from 1974 onwards, replacing it with the Golf. At this stage Volkswagen AG considered opening a plant in the USA for the production of its new model and the Pennsylvania plant was opened in 1978. Uhl argued that German workers and the Wolfsburg works council in particular were concerned by this development. The perception existed that jobs would be lost in Germany and production shifted to the new plant. Competition would emerge between the new plant and the older ones located in Germany. Further expansion into Spain occurred when it was agreed to build the Volkswagen Polo at the SEAT plant in Pamplona.70 This meant there could be direct competition between the plants producing the same models. Indeed, Folker Fröbel, Jürgen Heinrichs and Otto Kreye argued that labour movements in industrial countries needed to recognize that in the new international 
division ... to defend their own interests in isolation from the labour movements in the developing countries is self-defeating'.71 In addition, Volkswagen could be vulnerable to negative public exposure because of the investments in South Africa.72 Nonetheless, South Africa still represented a financially attractive option to Volkswagen AG as German plants benefited from supplying the Uitenhage subsidiary.

The international expansion of Volkswagen and the supposed threats of competition and negative publicity meant that the company and the works councils began to look beyond the borders of West Germany. As a result, Uhl was tasked with arranging a fourteen-day programme for a South African delegation made of up of black and white trade-union representatives and management in 1978, 'to show them plants and the climate, how we worked together ... [and] how the union is playing a role in responsibility'.73 He was able to meet with the black and coloured delegates away from the white managers and unionists - Uhl and John Gomomo of the UAW became close friends. A direct consequence of the visit to Germany was the scrapping of some elements of 'petty apartheid' in the Uitenhage plant, such as the abolition of separate toilets and water fountains for different racial groups.

Robert Steiert of the IMF highlighted the difference between German and South African management, referring to having to 'push a little from Germany'.74 This refers to the pressure the works councils exerted on Volkswagen AG management. Volkswagen's director of personnel, Karl-Heinz Briam, visited Uitenhage in July 1979 and maintained there should be equal wages for equal work, and committed Volkswagen to further training of black workers. Briam corresponded with Rademeyer and stated:

whatever happens in Brazil, SA, Mexico, the USA ... it immediately has an effect and receives detailed coverage in the mass media in Germany and Europe ... When giving advice to our subsidiaries we expect of them and encourage them to go as far as is allowed i.e. to stretch and interpret the laws of their country as far as possible in all questions of VW philosophy.75

The emerging shop-floor relationship between Wolfsburg and Uitenhage was strengthened during industrial action in the latter. In June 1980, industrial action engulfed Uitenhage as a deadlock was reached during negotiations over wages at VWSA. The union demanded a 'living wage' of R2 per hour. Report-back meetings to the general work-force planned for 15 June 1980 were banned. The IMF and IG Metall were alerted in anticipation of the strike. On the fourth anniversary of the Soweto uprising, Uitenhage was embroiled in strike activity. The South African police dispersed and tear-gassed workers at the neighbouring Goodyear, Hella and SKF plants, and workers were either dismissed or forced to return to work under police escort. At Volkswagen the scene played itself out quite differently. Volkswagen AG warned the subsidiary to maintain restraint. Briam phoned Uitenhage, and stated: 'VW AG was under considerable pressure in Germany from their employees, television and press ... [He] urged VWSA management to avoid termination of strikers [sic]'.76 A telex from Germany was sent to Uitenhage addressed to the 'Worker representatives in the factory committee' from the chairs of the works councils at each of the six Volkswagen German plants. It wished success with the 
negotiations and stated that 'we have done everything in our power in the discussions with the board of the Volkswagenwerk AG to emphasize the fact that everything should be explored which might contribute to a just solution'.77

Volkswagen workers rejected the increased offer of R1.40 per hour, and management threatened to dismiss striking workers. With the assistance of the IMF, the offer was increased to R1.45, and management finally agreed to pay R2 per hour within eighteen months. Volkswagen workers had stayed out on strike for more than three weeks, and returned with a wage increase, no loss of jobs, and a more powerful union.78 The IMF and IG Metall had been able to influence the outcome of the strike. Karl Casserini of the IMF took part in the negotiations with VWSA management and over $£ 38,000$ was collected for the strike from abroad.79 Rebhan of the IMF maintained that the role of international trade-union solidarity was important, as IG Metall and the Volkswagen works councils exerted pressure on the subsidiary not to dismiss any workers and to reach an agreement.

Communications between the trade unions in South Africa and Germany contributed to the pressure being exerted from Volkswagen management in Wolfsburg on their counterparts in the Uitenhage plant. Volkswagen AG wanted to avoid any kind of embarrassment, let alone international incident, at the subsidiary. As a consequence one immediate outcome of the strike was the establishment of a direct telex link between the Volkswagen shop stewards in Uitenhage and their German counterparts in Wolfsburg.80 Within the Uitenhage plant, the unions signed an agreement in September 1980 for full-time shop stewards, paid by the company, to be involved in union matters.81 Volkswagen was the first company in South Africa to agree to this.

This period under review highlights a number of contradictions. An emerging radical black trade union fighting for recognition within the plant and against apartheid more generally had linked up with the more conservative IG Metall and quasi-managerial works council structure in Germany. These linkages resulted in trade-union recognition; abolition of certain forms of petty apartheid in the Uitenhage plant; pressure being exerted on South African management by their German counterparts; direct means of communications and personal relationships. In addition, the Uitenhage plant was thrust into the public eye, in Germany in particular, and this meant that South African management fell under increasing pressure from the company's headquarters but also from an emerging trade union within the plant which had direct access to German union structures and bodies.

The developing contact, linkages, internationalism and solidarity were the result of several factors. First, the emerging independent trade-union movement in South Africa, generally, and the plant, in particular, was able to organize and become a visible force within Uitenhage. Second, affiliates to the IMF had pressurized it to take a more prominent and active engagement in South Africa. Due to IG Metall's dominance of the IMF, the more radical position of boycotts and isolation would not be entertained. Rather, 'constructive engagement' through visits took place that resulted in linkages with black trade unions. Such contact served the institutional interests of all three bodies: the IMF, IG Metall and the emerging black trade union. Third, Volkswagen management in Germany pressured its subsidiary to act with restraint during periods of industrial action and to 'stretch and interpret' South African law in line with the 'Volkswagen philosophy'. Finally, Volkswagen's works councils in Germany were concerned with the company's expansion into Spain and the USA as 
this may have led to the loss of German jobs, competition emerging between plants, and negative publicity because of the South African subsidiary. Building relations with black South African unions thus helped to protect the economic interests of the works councils.

While the emerging contact was primarily driven by defensive moves by top officials it nevertheless created a framework for international workers' solidarity to develop. Despite the differences and differing motivations of the actors, internationalism and solidarity was developed and displayed with the black trade union in the plant. Importantly, personal contacts were developed between South African shop stewards and German works councillors and union advisers, which came to embody a generational experience of a particular form of internationalism. This contact was confined to the trade union and works council structures, which meant that issues external to the plant were secondary. The German churches' engagement in South Africa and with Volkswagen in particular changed this.

The German churches and the emergence of the International Solidarity Groups

The Protestant Church in Germany opposed apartheid in South Africa and published on the topic in the early 1970s and 1980s. The publications represented critical interventions in the debate on apartheid. By1975, the Kirchliche Dienst in der Arbeitswelt (KDA, church service in the world of work) of the Evangelical Church, which represented a community of Lutheran, Reformed and United regional churches in Germany, questioned the role of German TNCs in South Africa. The KDA had been established to help Christians at workplaces with socio-political issues and was independent of companies and unions. It was explicit in its call for the eradication of apartheid and a close monitoring of the efficacy of the EEC Codes of Conduct. Out of this concern arose a study tour to South Africa comprised of members of the Volkswagen Wolfsburg works council, the KDA and EvangelicalLutheran Mission in Lower Saxony. Initial discussions occurred in June 1980 but by early 1981 'no personal relationships of trust existed with other church members' and at this stage the Volkswagen colleagues would not participate in the tour.82 Yet, by March 1981 the works council members had agreed to participate, so planning for the study tour resumed. Hermann Hartmann, a KDA representative, suggested:

IG Metall in Frankfurt wasn't so happy with our programme ... [I]t was not under their umbrella and they were a little bit afraid that we could bring not opportune information to the Volkswagen people ... meet different persons to whom the IG Metall had no access, see the political situation out of South Africa with different views and not concentrating only on Volkswagen.83

In February 1982, an eleven-member delegation, comprising works council and IG Metall members, including Uhl, embarked on a fourweek study tour of South Africa with the goal of exposing participants to life outside the factory and to experience the realities of apartheid. The study tour left lasting impressions on delegates. Uhl, in particular, recalled that he met with members of the underground movement and this 
'could happen with the church contacts'.84 In the same month, the Food and Canning Workers Union organizer, Neil Aggett, died in police custody in John Vorster Square, the police headquarters in Johannesburg. The German delegation joined the 15,000-strong procession through Johannesburg's Westpark cemetery. Mike Murphy, the Federation of South African Trade Unions (FOSATU) international officer, commented on the role played by the German church: 'what appears from this is the potential usefulness of church bodies in Germany as pressure groups. The unions in Germany seem to allow the churches to "preach at" them without getting too offended'.85 This engagement by the German churches influenced the members of Volkswagen's works council and resulted in further study tours during the 1980s. Searle and Rademeyer both suggested that 'various church groups were the main lobbyists against VWSA's operation'.86 The visits organized by the German churches shifted the focus away from the shop floor to broader socio-political issues. In 1982, three International Solidarity Groups (Intersoli) were established by IG Metall Wolfsburg for South Africa, Brazil and Mexico. The remit of the Intersoli groups was to look beyond the Volkswagen subsidiaries in the three countries, by educating themselves about social and political realities and the working conditions in the countries. A bank account was established to aid South African and Brazilian workers specifically. 87

In a leaflet circulated by the Intersoli group certain explicit political positions in line with the ANC and the Anti-Apartheid Movement were adopted.88 The leaflet called for an 'active' politics against the white-minority regime, and suggested that Helmut Kohl (leader of the Christian Democrats and then German Chancellor, 198298) and Franz Josef Strauss (the other dominant right-wing politician, leader of the Christian Social Union and premier of Bavaria at the time) directly supported the Pretoria regime. Among its demands, the leaflet outlined the call of trade unions affiliated to the DGB89 for: the downgrading of the German embassy in South Africa to observer status; introduction of visa requirements for South African citizens wishing to visit Germany; suspension of landing and flying rights over Germany by South African Airways; and suspension of services by Lufthansa (then the German state-owned airline) to South Africa.

The Intersoli group visited South Africa in 1988 and the delegation met with the IMF in Johannesburg, National Union of Metalworkers of South Africa shop stewards and management from the Volkswagen plant in Uitenhage, the Congress of South African Trade Unions (COSATU) officials in Port Elizabeth, the South African Council of Churches, the Black Sash, and Uitenhage Town Council. In discussions with the shop stewards, issues such as disinvestment, the role of VWSA in charity work in KwaNobuhle, the Uitenhage township where many Volkswagen workers resided, and trade-union work regarding salaried workers, were considered. In a subsequent report, the delegations stated that what 'we saw and experienced with our very eyes ... made a deep impression on all of us and each of us individually'.90 The report suggested contacting the German Anti-Apartheid Movement to 'participate in their discussion, in order to broaden the base of future actions, in order to bring in our trade union opinion'.91 Moreover, it was suggested that ANC representatives in Bonn should be contacted in order to obtain further information on South Africa.

Although Intersoli groups for South Africa,92 Brazil and Mexico were only established in Wolfsburg and at no other Volkswagen plant in Germany, their activities were explicitly political and intentionally moved beyond shop-floor issues. This in turn meant that, similar to the visits arranged by the churches, the Intersoli 
group experienced conditions outside the plant in apartheid South Africa. The initial fears of South African management regarding the influence of the German churches came to fruition with the establishment of Intersoli.

The Intersoli group were made up of activists from a variety of backgrounds in the Wolfsburg plant, showing that worker solidarity could develop outside the ambit of official trade-union linkages. Yet Intersoli itself faced a contradictory situation as, on the one hand, it adopted positions in line with the Anti-Apartheid Movement and, on the other hand, acknowledged that its existence was a result of Volkswagen investing in South Africa. Despite the apparent initial independence of the Intersoli group, it depended on the Wolfsburg works council, through which all communication with South Africa was handled. The possibility of a wider form of worker solidarity was created, but its development was limited by the interests of the works council and, in turn, of the company.

The contact initiated by the church went beyond the ambit of shopfloor and labour relations issues, and this did not necessarily impact on industrial relations policies at Volkswagen. Rather its role moved the German trade-unionists beyond their narrow institutional and economic interest of trade-union recognition, job security and wages. The initiatives of the church brought German trade-unionists into contact with broader forces in the struggle against apartheid that included banned members of the underground. Therefore the church's role in moving union actors beyond the economic and institutional agendas towards the political is significant.

\section{Conclusion}

The contacts, relationships, internationalism and solidarity displayed in this case study are unique. As a result of the emergence of black trade unions after 1973 and the worldwide outcry after the 1976 Soweto uprising, the IMF was forced to engage pro-actively in the debate on South Africa. Despite being under pressure from affiliates to push for boycotts and isolation, the more conservative western unions, such as IG Metall, adopted the approach of 'constructive engagement' within the IMF. Therefore, because of the dominant role it played within the IMF, IG Metall became engaged in the debate on apartheid South Africa.

Due to Volkswagen AG's approach to industrial relations and codetermination in particular, it was keen to bring about labour stability in the Uitenhage plant. For this to take place, recognized negotiating partners had to exist within the subsidiary. South African legislation did not permit the recognition of black trade unions; however, through pressure from the IMF and management in Germany, this unusual step took place. Volkswagen was keen to highlight what was indeed progressive at the time, to the German public in particular, and this in turn meant reciprocal visits to Germany and South Africa occurred. One of the first outcomes of such a visit was the scrapping of certain forms of petty apartheid within the Uitenhage plant.

The Uitenhage subsidiary was therefore thrust into the spotlight. One outcome was that the management of Volkswagen in German urged restraint during the industrial action at Uitenhage in 1980. The IMF also helped to find a settlement to the strike. These emerging relationships were filtered through specific interests. First, the South African union demanded recognition from the company, giving it certain 
rights within the plant; here the institutional interests of the union are apparent. Second, the IMF, IG Metall and the Volkswagen works councils wanted to protect German investments within South Africa as there could have been a detrimental effect on German levels of employment if the Uitenhage plant were closed. To legitimize their position in South Africa, certain rights would have to be conceded to South African labour. In addition, emerging competition within the Volkswagen group had to be avoided. Thus the economic interests of the unions and works councils and indeed the company are clear. Finally, Volkswagen AG came under increasing pressure from the Anti- Apartheid Movement and churches within Germany to withdraw from South Africa. Again, to legitimize the Uitenhage operation it had to be seen as progressive in pushing for certain rights for the black trade union.

The narrow forms of economically deterministic trade-unionism had limitations, as the focus of engagement was at the bureaucratic, institutional and shop-floor levels. For this reason, the German churches' engagement within South Africa and their role in politicizing the relationships are crucial. One of the consequences of this engagement was the formation of the Intersoli group. Despite its obvious limitations, it played an important counteracting role to the crudely instrumental economic and institutional interests of the other actors.

Finally, an important lesson of this experience is that solidarity and internationalism can be built out of the articulation and reformulation of interests that workers and unions embrace in specific workplaces, firms and countries. Such solidarity and internationalism cannot be taken for granted or simply invoked ideologically. Rather they have to be built and rebuilt by addressing, reconciling and sometimes challenging existing conceptions of economic, institutional and political interests. Furthermore, the forms of solidarity and internationalism that have been documented have, even in more successful phases, been marked by tensions and limitations, which have to be recognized. The ways in which solidarity and internationalism are developed will necessarily be influenced by specific economic and political contexts in which workers and unions are operating, so the forms they take will need to be rethought and reconstructed in changing circumstances.

School of Languages and Social Sciences Aston University, Birmingham B4 7ET

\section{Notes}

1. E. Webster, 'Sanctions against Apartheid', South African Labour Bulletin 14:7 (1990), pp. 54-8.

2. The data examined in this paper was part of a broader research project: $\mathrm{C}$. Bolsmann, 'Trade Union Internationalism and Solidarity in the Auto Industry: Fighting Apartheid and Engaging with Globalisation' (Ph.D., University of Warwick: 2005). This included semi-structured interviews with sixty-one active and retired trade-unionists, works councillors, managers and activists in Germany, South Africa, Spain and Switzerland, who were, and in some cases still are, important actors in the case study

3. J. Baskin, Striking Back: A History of COSATU (Ravan Press, Johannesburg: 1991). 
4. For an official history of the South African Congress of Trade Unions (SACTU), see K. Luckhardt and B. Wall, Organize ... or Starve! The History of the South African Congress of Trade Unions (Lawrence and Wishart: 1980).

5. S. Friedman, Building Tomorrow Today - African Workers in Trade Unions 19701984 (Ravan Press, Johannesburg: 1987), p. 27.

6. Baskin, Striking Back: A History of COSATU, p. 13.

7. Ibid., p. 15.

8. Ibid.

9. Friedman, Building Tomorrow Today, p. 32.

10. R. Lambert, 'Political Unionism in South Africa: An Analysis of the South African Congress of Trade Unions' (Ph.D., University of the Witwatersrand: 1989).

11. Baskin, Striking Back, p. 16.

12. J. Maree (ed.), The Independent Trade Unions, 1974-1984: Ten Years of the South African Labour Bulletin (Ravan Press, Johannesburg: 1987), chronicles the establishment of the South African Labour Bulletin in tandem to the emerging independent unions. Independent trade unions were "black, predominantly African ... free from control of white unions ... [and over time] incorporated trade union autonomy from both the state and employers': ibid., p. viii.

13. Friedman, Building Tomorrow Today, p. 40.

14. Ibid., p. 2.

15. Ibid., p. 51; see V. L. Allen and K. Carey, 'Notes on Research for a History of Black Mineworkers in South Africa', Historical Studies in Industrial Relations 20 (Autumn 2005), p. 108, n. 7, for the reports and minutes of evidence of this Select Committee.

16. See T. Sellström, Sweden and National Liberation in Southern Africa, Vol. 2: Solidarity and Assistance 1970-1994 (Nordiska Afrikainstitutet, Uppsala: 2002); R. Fieldhouse, Anti-Apartheid: A History of the Movement in Britain. A Study in Pressure Group Politics (Merlin Press: 2005); H. Thörn, Anti-Apartheid and the Emergence of a Global Civil Society (Palgrave Macmillan, Basingstoke: 2006).

17. These include R. Gumbrell-McCormick, 'Facing New Challenges: The International Confederation of Free Trade Unions (1972-1990s)', in M. van der Linden (ed.), The International Confederation of Free Trade Unions: A History of the Organization and its Precursors (Peter Lang, Bern: 2000), pp. 341-517; I. Macun, 'Trade Union Internationalism and the Independent Union Movement in South Africa: A Preliminary Account' (BA Honours Project, University of Cape Town: 1984); R. Southall, 'The Development and Delivery of "Northern" Worker Solidarity to South African Trade Unions in the 1970s and 1980s', Journal of Commonwealth and Comparative Studies (JCCS) 32 (1994), pp. 166-99; R. Southall, Imperialism or Solidarity? International Labour and South African Trade Unions (UCT Press, Cape Town: 1995); D. Tenzer, 'The IG Metall and the Black Metal Unions in South Africa: Impact and Political Framework of International Trade Union Solidarity Against Apartheid 1972-1989' (MA dissertation, University of Hanover: 1998).

18. Southall, Imperialism or Solidarity?

19. Southall, 'Development and Delivery of "Northern" Worker Solidarity to South African Trade Unions', JCCS.

20. Ibid., p. 195.

21. Ibid.

22. Tenzer, 'The IG Metall and the Black Metal Unions in South Africa'.

23. R. Zoll, Was ist Solidarität heute? (Suhrkamp, Frankfurt am Main: 2000). 
24. A number of shop-floor contacts were developed in other trans-national corporations (TNCs), including the British Leyland plant in Solihull in England and the Cape Town subsidiary: South African Labour Bulletin 5:8 (1980). None had the same longevity and impact as those within Volkswagen.

25. The Population Registration Act of 1950 required all South Africans to be classified in terms of racial groups and these included Asians, Blacks, Coloureds and Whites. For purposes of clarity these categories are used in this paper.

26. These figures depicted are for 1998. International Labour Organization (ILO), The Social and Labour Impact of Globalization in the Manufacture of Transport Equipment: Report for Discussion at the Tripartite Meeting on the Social and Labour Impact of Globalization in the Manufacture of Transport Equipment (ILO, Geneva: 2000), p. 109.

27 U. Jürgens, 'The Development of Volkswagen's Industrial Model 1967-1995', in M. Freyssenet, A. Mair, K. Shimizu and G. Volpato (eds), One Best Way? Trajectories and Industrial Models of the World's Automobile Producers (Oxford University Press: 1998), pp. 273-7.

28. Ibid., p. 273.

29. Ibid., p. 274.

30. A. S. Markovits, The Politics of the West German Trade Unions: Strategies of Class and Interest Representation in Growth and Crisis (Cambridge University Press: 1986), p. 186.

31. Ibid., p. 188.

32. Ibid.

33. R. Hyman, Understanding European Trade Unionism: Between Market, Class and Society (Sage: 2001), p. 126.

34. Ibid.

35. Markovits, The Politics of the West German Trade Unions, p. 133.

36. Hyman, Understanding European Trade Unionism, p. 127.

37. Jürgens, 'The Development of Volkswagen's Industrial Model', p. 276.

38. Markovits, The Politics of the West German Trade Unions, p. 183.

39. Agreement of Sale of Purchase between the Municipality of Uitenhage and the South African Motor Assemblers and Distributors Limited, 27 November 1946/23 January 1947, Vol. 1, 55F, Archives of the Port Elizabeth Municipality.

40. Evening Post, 13 July 1962.

41. Evening Post, 15 March 1964.

42. D. Duncan, We Are Motor Men: The Making of the South African Motor Industry (Whittles Publishing, Latheronwheel: 1990).

43. M. C. Roux, 'Perspectives and Values of Industrial Workers: The Emergence of Socio-Economic Consciousness amongst Coloured Workers in the Motor Manufacturing Industry in the Eastern Cape' (Ph.D., University of Stellenbosch: 1977).

44. Friedman, Building Tomorrow Today, p. 72.

45. Baskin, Striking Back, p. 160.

46. Ibid.

47. Roux, 'Perspectives and Values of Industrial Workers'.

48. G. Adler, "'The Factory Belongs to All Who Work in It": Race, Class, and Collective Action in the South African Motor Industry, 1967-1986' (Ph.D., Columbia University: 1994), p. 225.

49. Bantu referred to black workers. 
50. J. Maree and D. Budlender, 'Overview: State Policy and Labour Legislation', in Maree, The Independent Trade Unions, p. 118.

51. Volkswagen of South Africa (VWSA), A History of Volkswagen of South Africa (VWSA, Uitenhage: 1976), p. 20.

52. Southall, Imperialism or Solidarity?, p. 108.

53. Luckhardt and Wall, Organize ... or Starve!, p. 380.

54. Southall, Imperialism or Solidarity?, p. 109.

55. E. Webster, 'Review of Southall, Imperialism or Solidarity?', Journal of Contemporary African Studies 15:2 (1997), pp. 324-7.

56. Southall, Imperialism or Solidarity?, p. 229.

57. Ibid., p. 233.

58. Überweisung der DM 50.000.- für südafrikanische Flüchtlinge. Frankfurt April 27, 1964. Archives of the Friedrich Ebert Stiftung, Bonn.

59. International Metalworkers' Federation (IMF), International Metalworkers'

Federation 1893-1993: The First Hundred Years (IMF, Geneva: 1993), p. 57.

60. J. Mke, letter to O. Rademeyer, 24 February 1977, Archives of the FriedrichEbert-Stiftung, Bonn.

61. H. Rebhan, and W. Thönnessen, 'Der IMB und die Metallgewerkschaften in Südafrika 1951 bis 1982', in E. Loderer (ed.), Metallgewerkschaften in Südafrika (Otto Brenner Stiftung, Frankfurt am Main: 1983), p. 147; Tenzer, 'The IG Metall and the Black Metal Unions', p. 104.

62. Quoted in Adler, “'The Factory Belongs to All Who Work in It"', p. 242.

63. Quoted in V. Mertens, Europaweite Kooperation von Betriebsräten multinationaler Konzerne. Das Beispiel des Volkswagen-Konzerns (Deutscher Universitäts-Verlag, Wiesbaden: 1994), p. 287.

64. E. Loderer and H. Rebhan, Metaller in Südafrika: Ein Reisebericht von Eugen Loderer und Herman Rebhan (IMF, Geneva: 1978), pp. 35-6.

65. South African Labour Bulletin, 'The Codes of Conduct and Trade Unions', South African Labour Bulletin 4:7 (1978), pp. 1-3.

66. Ibid., p. 1.

67. Ibid., p. 2.

68. Ibid.

69. Interview, H.-J. Uhl (general secretary of the Volkswagen European Group Works Council and the Volkswagen World Group Works Council), Wolfsburg, 29 August 2003.

70. Mertens, Europaweite Kooperation von Betriebsräten multinationaler Konzerne.

71. F. Fröbel, J. Heinrichs and O. Kreye, 'The New International Division of Labour', South African Labour Bulletin 5:8 (1980), p. 15.

72. Interview, A. Schunk (former International Officer of IG Metall), Palma de Mallorca, 9 September 2003.

73. Interview, Uhl.

74. Interview, R. Steiert (former official of IG Metall, now employed by the IMF), Geneva, 18 August 2003.

75. M. Tschirschwitz, 'A Study to Evaluate the Effect of a German Multi-National Company on its South African Subsidiary's Labour Relations Policies' (Honours Research Project: University of Port Elizabeth: 1990), p. 84.

76. N. B. H. Faull, A Case Study of the Volkswagen Strike 1980 (Graduate School of Business, University of Cape Town: 1981), p. 27.

77. Ibid., p. 40.

78. Adler, "'The Factory Belongs to All Who Work in It"', p. 96. 
79. D. Macshane, M. Plaut and D. Ward, Power! Black Workers, Their Unions and the Struggle for Freedom in South Africa (Spokesman, Nottingham: 1984), p. 131.

80. Ibid., p. 132.

81. Faull, $A$ Case Study of the Volkswagen Strike.

82. H. Hartmann, 'Abschlussbericht des Projektes: Gerechtigkeit und Solidarität in der internationalen Wirtschaftsordnung' (Kirchliche Dienste in der Arbeitswelt, unpublished report: 1982), p. 6.

83. Interview, Hermann Hartmann (representative of Church Development Service of the Evangelical Lutheran Church of Braunschweig and Hanover), 28 August 2003, Hildesheim.

84. Interview, Uhl.

85. M. Murphy, 'Further developments relating to the German and French trade unions following various visits, including Fosatu visitors in February/March and May '82. 22 June 1982', AH 2065/G6.2, Taffy Adler, International Organizations, University of the Witwatersrand Historical Papers.

86. Tschirschwitz, 'A Study to Evaluate the Effect of a German Multi-National Company', p. 116.

87. Ibid.

88. Intersoli, 'South Africa - Land of Apartheid. This means: murder, torture, racism, press censorship etc' (unpublished report: n.d.).

89. Deutscher Gewerkschaftsbund, the main trade-union confederation in Germany.

90. Intersoli, 'Report on the Study Tour by Members of the International Solidarity Group of the IG Metall Wolfsburg to South Africa from May 12 till May 28, 1988' (unpublished report: 1988), p. 18.

91. Ibid., p. 19.

92. In the case of South Africa due to the relationship that had emerged in the late 1970s between Uhl and John Gomomo, in particular. 